\title{
Formation of submicron colloidal particles from marine bacteria by viral infection
}

\author{
A. Shibata, K. Kogure, I. Koike, K. Ohwada* \\ Ocean Research Institute, University of Tokyo, Nakano, Tokyo, 164, Japan
}

\begin{abstract}
We tested the hypothesis that viral lytic infection leads to the formation of submicron-sized colloidal particles originating from marine bacteria. Laboratory experiments were performed using a manne bacterium, Vibrio alginolyticus, and and its infectious phage. A particle counter was used to determine abundance and size distribution of particles. We found that the non-living submicron sized particles (size range from 0.38 to $0.7 \mu \mathrm{m}$ in diameter) increased rapidly along with a decrease of bacteria and an increase of phage, indicating that these particles are cell debris originating from bacteria. These particles were stained faintly by acridine orange but were not countable due to the amorphous shape. These results show that amorphous submicron particles are produced by viral lysis of bacteria. This process may be one of the major pathways of colloid formation associated with microbial food webs in the sea.
\end{abstract}

KEY WORDS: Virus Phage Marine bacteria - Submicron particles Marne colloids

Recently, non-living colloidal particles (approximate size range, 0.005 to $1 \mathrm{\mu m}$ ) have been found to be abundant in marine environments (Koike et al. 1990, Wells \& Goldberg 1991, 1994, Longhurst et al. 1992, Sieracki \& Viles 1992). Their sources and sinks are interesting from an ecological and biogeochemical point of view, because high molecular weight dissolved organic carbon (HMW-DOC) including such colloids (1) represents a significant fraction of the bulk DOC (Benner et al. 1992, Ogawa \& Ogura 1992, Guo et al. 1994), and (2) is important as reactive components of DOC (Moran \& Buesseler 1992, Amon \& Benner 1994, Santschi et al. 1995)

Little is known about the actual mechanism of colloid formation in natural seawater Distribution of the sub-

\footnotetext{
-Addressee for correspondence.

E-mail:ohwada@or.u-tokyo.ac.jp
}

micron-sized colloids determined using a particle counter was found to be correlated with bacterial concentration and some other biological parameters, suggesting that their formation is associated with biological activities (Koike et al. 1990). Microorganisms including phytoplankton, flagellates and bacteria have been suggested as the sources of colloids using laboratory culture experiments (Decho 1990, Passow et al. 1994) The egestion of bacteria by mixotrophic and heterotrophic flagellates have been reported as one important process of colloid formation (Koike et al. 1990, Nagata \& Kirchman 1992, Tranvik 1994). Microbial processes, especially mortality, seem to be one of the key factors in the formation of marine colloids.

Observations with transmission electron microscopy (TEM) have clarified that free-living virus-like particles are abundant in aquatic environments (Bergh et al. 1989, Bratbak et al. 1990). The presence of viral particles within bacteria, cyanobacteria and small eucaryotes suggests significant mortality due to viral infection (Proctor \& Fuhrman 1990, 1991). It can be hypothesized that bacterial lysis by viruses may result in the release of colloids such as macromolecules and small cellular debris in seawater (Bratbak et al. 1990. Heldal \& Bratbak 1991, Proctor \& Fuhrman 1991, Wells \& Goldberg 1992, 1994, Zweifel \& Hagström 1995). However, whether or not this virus pathway results in the formation of marine detrital colloids has not yet been clarified.

In order to confirm the formation of colloidal particles by viral infection of bacteria, we conducted laboratory experiments with phage infectious to a marine bacterium, Vibrio alginolyticus. The results suggest the formation of colloidal particles associated with viral lysis of bacteria in natural seawater. In this work, we define submicron particles as those ranging from 0.38 to $0.7 \mu \mathrm{m}$ determined by the particle counter. This size range practically excludes bacterial cells 
Materials and methods. Isolation of phage: A bacteriophage named VA1 was isolated from surface water in Aburatubo Inlet, Kanagawa, Japan, on May 1, 1991. The seawater sample was serially filtered through Millipore filters (pore-size, 0.65 and $0.22 \mu \mathrm{m}$ ) and the host bacterium Vibrio alginolyticus (NCMB 1903) was inoculated with $0.25 \%$ yeast extract. After incubation for $3 \mathrm{~d}$ at $20^{\circ} \mathrm{C}$ in a glass bottle, enriched phage infectious to $V$. alginolyticus was isolated by the standard plaque assay (Suttle 1993) using $1 / 2$ strength ZoBell 2216E medium.

Culture conditions: Bacteria + phage mixed culture was grown in $1 / 20$ strength ZoBell $2216 \mathrm{E}$ medium based on artificial seawater $\left(\mathrm{NaCl}, 30 \mathrm{~g}_{i} \mathrm{MgSO}_{4} \cdot 7 \mathrm{H}_{2} \mathrm{O}, 4 \mathrm{~g}\right.$; $\mathrm{KCl}, 0.8 \mathrm{~g}_{\mathrm{C}} \mathrm{CaCl}_{2}, 1.2 \mathrm{~g}$; HEPES ( $\left.\mathrm{pH} 7.6\right), 11.92 \mathrm{~g}_{\text {; }}$ in $1 \mathrm{l}$ distilled water). The medium was filtered (Millipore, pore size, $0.22 \mu \mathrm{m}$ ) before autoclaving to remove the particles in the submicron size range. We also prepared bacterial pure culture as a control in the same culture condition. The bacterial cells $\left(2\right.$ to $3 \times 10^{5}$ cells $\mathrm{ml}^{-1}$ ) and phage VA 1 [ 1 to $2 \times 10^{4} \mathrm{PFU}$ (plaque forming units) $\mathrm{ml}^{-1}$ ] were inoculated to the medium and then incubated at $20^{\circ} \mathrm{C}$ with gentle shaking. Subsamples were taken, and those for determination of bacteria and particle size distribution were fixed with $0.22 \mu \mathrm{m}$ prefiltered formaline (final concentration, $2 \%$ ). The experiments were repeated to confirm the reproducibility.

Enumeration of bacteria and phage: Bacterial cells were counted under an epifluorescence microscope (Olympus, BH2-RFCA) using the acridine orange direct counting method (Hobbie et al. 1977). At least 300 cells and 10 fields were counted. PFU of phage VA1 were counted by the standard plaque counting method (Suttle 1993) using $1 / 2$ strength ZoBell $2216 \mathrm{E}$ medium after $2 \mathrm{~d}$ of incubation at room temperature. Chloroform (final concentration $1 \%$ ) was used to kill phageresistant bacterial cells immediately after sampling.

Determination of particle size distribution: Submicron particles were counted with the Elzone Particle Counter $80 X Y$ (Particle Data Inc., USA), equipped with a $12 \mu \mathrm{m}$ orifice counting tube (Kogure \& Koike 1987). The countable size range using this tube was 0.38 to $4.03 \mu \mathrm{m}$ equivalent spherical diameter. The current and gain were set at 1.5 and 1.0 , respectively. The conductivity of the samples was normalized for each one. Sam.ples were diluted with $0.22 \mu \mathrm{m}$ (Millipore filter) filtered $3.5 \% \mathrm{NaCl}$ solution which was prepared with fresh distilled water. All samples were analyzed within 30 min after sampling. Measurements were repeated consecutively at least 3 times and the average values are shown. as results. The coefficient of variation was less than $10 \%$.

Results and discussion. In the mixed culture, the abundance of phage VA 1 started to increase soon after the start of incubation and reached ca $1 \times 10^{8} \mathrm{PFU} \mathrm{m} \mathrm{m}^{-1}$ after 4 h (Fig 1). Bacterial abundance decreased with

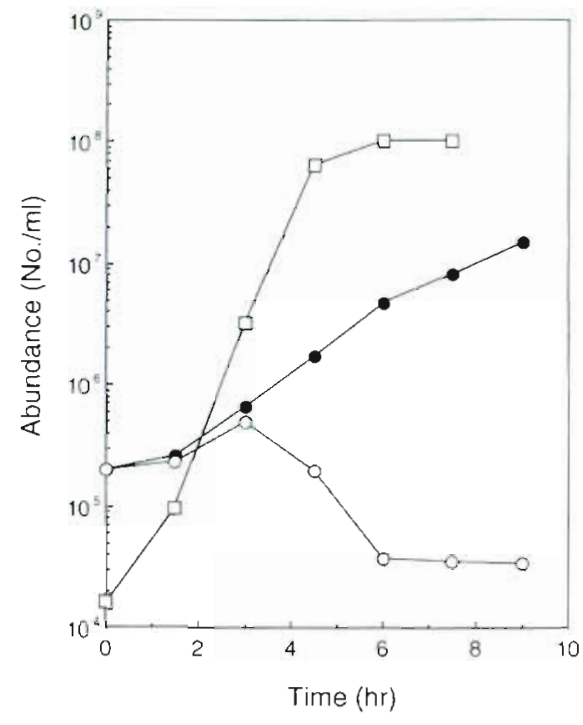

Fig. 1 Change in abundance in Vibrio algmolyticus + phage culture (mixture) and $V$. alginolyticus pure culture (control). (O) Bacterial. abundance in mixture. (-) Bacterial abundance in control. (a) Phage abundance counted as plaque forming units in mixture

the increase of PFU, indicating that bacterial cells were lysed by viral infection. With the decrease of bacterial abundance, fragile and amorphous materials which were weakly stained with acridine orange on the $0.2 \mu \mathrm{m}$ filters were seen. These were, however, not countable because of the faint staining and amorphous shape. Considering the shapes, these materials seem to be different from 'ghost cells', which are nonnucleoid-containing bacteria-like particles suggested by Zweifel \& Hagström (1995).

Under the same culture conditions, the change of particle size distribution was determined using the particle counter (Fig. 2). A single peak representing the siz: of bacterial cells appeared in the control during the incubation, although the size of the peak shifted slightly during incubation. In the mixed culture, considerable change in the particle size distribution was observed. The abundance of the submicron particles (size, 0.38 to $0.7 \mu \mathrm{m}$ ). which were apparently different from the size of bacterial cells, increased after $3 \mathrm{~h}$ and became dominant after $4.5 \mathrm{~h}$. These particles are not phage themselves, because TEM observation indicate that phage VA1 particles are less than $0.2 \mu \mathrm{m}$ in length (data not shown), a size which is not detectable by the particle counter. At $4.5 \mathrm{~h}$, the size distribution peak of the bacteria and the submicron particles were 1.5 and $0.51 \mu \mathrm{m}$, respectively. If there was no loss in the volume, this suggests that 1 bacterial cell might be broken into 27 pieces. Considering the possible dispersion of soluble fractions, however, this number should be the maximum estimation (see below). 


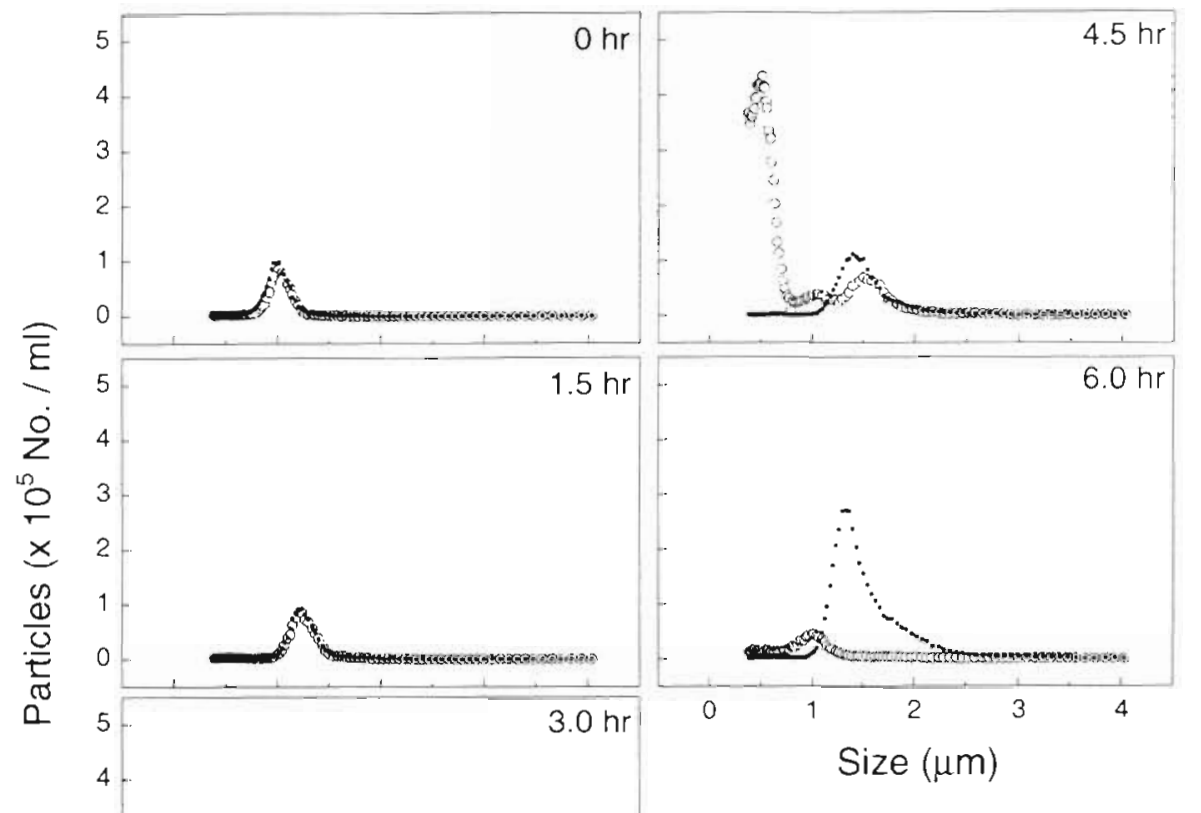

Fig. 2. Particle size distribution in Vibrio alginolyticus + phage culture (mixture) and $V$ alginolyticus pure culture (control). (o) Particle distribution in mixture. (•) Particle distribution in control

The change of particle abundance during incubation is shown in Fig. 3. The total particles (size, 0.38 to $4.03 \mu \mathrm{m}$ ) are those measured by the particle counter, and should include both bacteria and other particles. Bacterial abundance was obtained by epifluorescent microscopy. In the control, the increase of the total particles was due to bacterial growth. In contrast, the submicron particles started to increase sharply after $2 \mathrm{~h}$ in the mixed culture, and made up the largest part of the total particles after $3.75 \mathrm{~h}$. The submicron particles increased with the production of phage (Figs. 1 \& 3), indicating that this submicron-sized bacterial debris was produced by viral infection. We tried to estimate the number of submicron particles originating from 1 bacterial cell. From 3.75 to $4.5 \mathrm{~h}$, the net decrease of bacteria in the mixed culture was $0.5 \times 10^{6}{\text { cells } \mathrm{ml}^{-1}}^{-1}$ and the net increase of submicron particles was $5.1 \times$ $10^{5} \mathrm{ml}^{-1}$. Therefore, roughly 10 particles might be released from 1 bacterium. Because gross production of submicron particles might be larger than apparent increase (Fig. 3), this should be a minimum estimation. Together with the estimation stated above, it is reasonable to assume that roughly 20 submicron particles were formed from a lysed bacterium.

In general, only lytic infection results in virus replication and death of the host cell (Hayes 1976). If a bac-
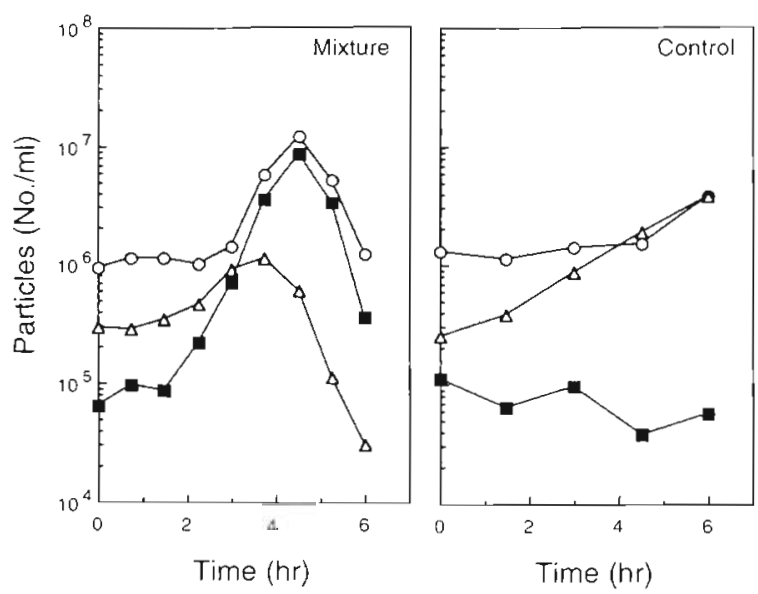

Fig. 3. Change in particle abundance in Vibrio alginolyticus + phage culture (mixture) and $V$. alginolyticus pure culture (control). (O) Total particles (sıze, 0.38 to $4.03 \mu \mathrm{m}$ ). ( $\triangle$ ) Bacteria. (ם) Submicron particles (sıze, 0.38 to $0.7 \mu \mathrm{m}$ )

terium is attacked by several of the phage, then a phenomenon known as 'lysis from without' occurs in which the phage weaken the bacterial cell wall to the point where lysis occurs without virus production (Delbrück 1940). In the present experiments, 'lysis from without' was not responsible for the increase of the submicron particles, because bacteria were much more abundant 
than phage in the mixture for the first $1.5 \mathrm{~h}$ and the particles still continued to increase with the production of phage VA1 (Figs. $1 \& 3$ ). These results indicate that the increase in the submicron particles was caused by typical viral lysis.

After $4.5 \mathrm{~h}$, the abundance of the submicron particles decreased rapidly in the mixed culture (Fig. 3), indicating the removal of the particles from the detectable size range $(0.38$ to $4.03 \mu \mathrm{m})$ of the particle counter. This rapid decrease was repeatedly observed under the experimental conditions of the present study. Although we have no further data, some possible hypethetical cases can be considered. First, fragmentation of the submicron particles into even smaller ones that are below the detection limit is a possible explanation for the decrease in submicron particles. Bacteria contain various ectoenzymes and cytoplasmic enzymes that might degrade those particles. Second, adsorption of these particles into the glass wall of the flask is also possible, because glass is known to adsorb biopolymers such as proteins. Third, aggregation of particles larger than $4.03 \mu \mathrm{m}$ might occur. Hydrophobic interaction of bacterial membrane components (for example, proteins and lipids) is probably an important factor in the case of adsorption and aggregation (Schulz \& Schirmer 1979, Kirchman et al. 1989) Although it is difficult to identify the reason for the decrease in submicron particles, our result indicates the unstable nature of the particles. More work is definitely needed to clarify the actual process causing this phenomenon.

Recent studies show that the viral contribution to bacterial mortality is similar to that of protists (Fuhrman \& Noble 1995, Steward et al. 1996) or that the former even occasionally prevails over the latter (Weinbauer \& Peduzzi 1995). If we assume that (1) 20 submicron particles are formed from 1 bacterial cell after viral lysis (disscussed above), (2) $1 \times 10^{6}$ bacterial cells ml $^{-1}$ were present, and (3) 10 to $20 \%$ of bacteria are lysed by viruses on a daily basis (Suttle 1994), then 2 to $4 \times 10^{6}$ colloidal particles $\mathrm{ml}^{-1} \mathrm{~d}^{-1}$ will be produced through viral lytic infection in natural seawater. Thus, this virus-pathway is likely to be important for the production of marine colloids in addition to the flagellate-pathway suggested previously (Koike et al. 1990, Nagata \& Kirchman 1992, Tranvik 1994).

In conclusion, our hypothesis that viral lysis leads to the formation of submicron-sized colloidal particles originating from host marine bacteria was confirmed. This suggests that viruses probably have the role as colloidal particle producers in the marine ecosystem. Although the actual contribution of viruses towards producing colloidal particles in natural seawater remains to be clarified, this process seems to have a considerable importance for the fate of dissolved organic matter in the ocean.
Acknowledgements. We thank Dr T. Nagata for comments and $K$. Terauchi for assistance with the experiments. We also thank the staff of the Misaki Marine Brological Station, University of Tokyo, for their kind help in collecting samples. This study was supported in part by the Sumitomo Foundation \# 93-104-745 and JSPS Research Fellowships for Young Scientists.

\section{LITERATURE CITED}

Amon RMW, Benner R (1994) Rapid cycling of highmolecular-weight dissolved organic matter in the ocean. Nature 369:549-552

Benner R, Pakulski JD, McCarthy M, Hedges JI, Hatcher PG (1992) Bulk chemical characteristics of dissolved organic matter in the ocean. Science 255:1561-1564

Bergh $\varnothing$. Børsheim KY. Bratbak G, Heldal M (1989) High abundance of viruses found in aquatic environments. Nature 340:467-468

Bratbak G, Heldal M, Norland S, Thingstad TF (1990) Viruses as partners in spring bloom microbial trophodynamics. Appl Environ Microbiol 56:1400-1405

Decho AW (1990) Microbial exopolymer secretions in ocean environments: ther role(s) in food webs and marine processes. Oceanogr Mar Biol Annu Rev 28:73-153

Delbruck M (1940) The growth of bacteriophage and lysis of the host. J Gen Physiol 23:643-665

Fuhrman JA, Noble RT (1995) Viruses and protists cause similar bacterial mortality in coastal seawater. Limnol Oceanogr 40:1236-1242

Guo L, Coleman Jr CH, Santschi PH (1994) The distrubution of colloidal and dissolved organic carbon in the Gulf of Mexico. Mar Chem 45:105-119

Hayes W (1976) The genetics of bacterla and their viruses, 2nd edn. John Wiley and Sons, New York

Heldal M. Bratbak G (1991) Production and decay of viruses in aquatic environments. Mar Ecol Prog Ser 72: 205-212

Hobbie JE, Daley RJ, Jasper S (1977) Use of Nuclepore filters for counting bacteria by fluorescence microscopy. Appl Environ Microbiol 33:1225-1228

Kirchman DL, Henry DL, Dexter SC (1989) Adsorption of proteins to surfaces in seawater Mar Chem 27:201-217

Kogure K, Koike I (1987) Particle counter determination of bacterial biomass in seawater. Appl Environ Microbiol 53: 274-277

Koike I, Hara S, Terauchi K, Kogure K (1990) Role of submicrometre particles in the ocean. Nature 345:242-244

Longhurst AR, Koike I, Li WKW, Rodriguez J, Dickie P, Kepkay P, Partensky F, Bautısta B, Ruiz J, Wells ML, Bird DF (1992) Sub-micron particles in northwest Atlantic shelf water. Deep Sea Res 39.1-7

Moran SB, Buesseler KO (1992) Short residence time of collords in the upper ocean estimated from ${ }^{238} \mathrm{U}-{ }^{239} \mathrm{Th}$ disequilibria. Nature 359:221-223

Nagata T, Kirchman DL (1992) Release of macromolecular organic complexes by heterotrophic marine flagellates. Mar Ecol Prog Ser 83:233-240

Ogawa H, Ogura $N$ (1992) Comparison of two methods for measuring dissolved organic carbon in sea water. Nature 356:696-698

Passow U, Alldredge AL, Logan BE (1994) The role of particulate carbohydrate exudates in the flocculation of diatom blooms. Deep Sea Res 41:335-357

Proctor LM, Fuhrman JA (1990) Viral mortality of marine bacteria and cyanobacteria. Nature 343:60-62 
Proctor LM, Fuhrman JA (1991) Roles of viral infection in organic particle flux. Mar Ecol Prog Ser 69:133-142

Santschi PH, Guo L, Baskaran M, Trumbore S, Southon J, Bianchi TS, Honeyman B, Cifuentes L. (1995) Isotopic evidence for the contemporary origin of high-molecular weight organic matter in oceanic environments. Geochim Cosmochim Acta 59:625-631

Schulz GE, Schirmer RH (1979) Principles of protein structure. Springer, New York, p 314

Sieracki ME, Viles CL (1992) Distributions and fluorochromestaining properties of submicrometer particles and bacteria in the North Atlantıc. Deep Sea Res 39:1919-1929

Steward GF, Smith DC, Azam F (1996) Abundance and production of bacteria and viruses in the Bering and Chukchı Seas. Mar Ecol Prog Ser 131:287-300

Suttle CA (1993) Enumeration and isolation of viruses. In: Kemp PF, Sherr BF, Sherr EB, Cole JJ (eds) Handbook of methods in aquatic microbıl ecology. Lewis Publishers, Boca Raton, p 121-134

This note was submitted to the editor
Suttle CA (1994) The significance of viruses to mortality in aquatic microbral communities. Microbral Ecol 28:237-243

Tranvik L (1994) Colloidal and dissolved organic matter excreted by a mixotrophic flagellate during bacterivory and autotrophy. Appl Environ Microbiol 60:1884-1888

Weinbauer MC. P'eduzzi P (1995) Significance of viruses versus heterotrophic nanoflagellates for controlling bacterial abundance in the northern Adriatıc Sea. J Plankton Res $17: 1851-1856$

Wells ML, Goldberg l:D (1991) Occurrence of small collords in sea water. Nature 353:342-344

Wells ML, Goldberg ED (1992) Marine submicron particles. Mar Chem 40:5-18

Wolls ML. (ioldberg ED (1994) The distribution of colloids in the North Atlantic and Southern Oceans. Limnol Oceanogr 39:286-302

Zweifel UL. Hagstrom A (1995) Total counts of marine bacteria include a large fraction of non-nucleoid-containing bacteria (Ghosts). Appl Environ Microbiol 61:2180-2185

Manuscript received: December 10, 1996 Revised version accepted: July 22, 1997 